UDK 342.722:616-036.22

Preliminary communication

\title{
ADMINISTRATION OF JUSTICE DURING THE COVID-19 PANDEMIC AND THE RIGHT TO A FAIR TRIAL
}

\author{
Krešimir Kamber, $\mathbf{P h D}^{*}$ \\ European Court of Human Rights \\ Ghent University Faculty of Law and Criminology \\ Allée des Droits de l'Homme, Strasbourg, France \\ Kresimir.Kamber@Ugent.be
}

\section{Lana Kovačić Markić, PhD candidate**}

Constitutional Court of the Republic of Croatia

Josip Juraj Strossmayer University of Osijek, Faculty of Law

Trg Svetog Marka 4, Zagreb, Croatia

lana_kovacic-markic@usud.hr

\begin{abstract}
On 11 March 2020 the World Health Organization announced the Covid-19 (coronavirus) to be a pandemic. To combat the pandemic, many countries had to adopt emergency measures and some of these measures have affected the judicial system, especially the functioning of courts. The pandemic has been characterised as far as the judiciary is concerned by complete or partial closure of court buildings for the parties and for the public. It is clear that the functioning of national judicial systems has been severely disrupted. This limited functioning of courts impacted the individuals' right to a fair trial guaranteed, in particular, under Article 6 of the European Convention on Human Rights. The aim of this article is to examine the manner of the administration of justice during the Covid pandemic and its impact on the due process guarantees. Focus is put on the extent to which different Covid measures, in particular remote access to justice and online hearings have impacted the guarantees of the right to a fair trial and the due process guarantees in general, notably in detention cases. In this connection, the article provides a comparative overview of the functioning of the European legal systems during the pandemic. It also looks into the way in which the two European courts - the European Court of Human Rights and the Court of Justice of the European Union functioned, as well as the way in which the Croatian courts, including the Constitutional Court, organised their work during the pandemic. The article then provides an insight into the issue of onlinelremote
\end{abstract}

Any opinion expressed in this Article is the author's personal opinion.

Ibid. 
hearings in the case-law of the European Court of Human Rights and in the Croatian Constitutional Court's case-law. On the basis of this assessment, the article identifies the differences in the use of remotelonline hearings between and within jurisdictions. In conclusion, the article points to some critical considerations that should be taken into account when devising the manner in which any Covid pandemic experience with the administration of justice (notably with regard to remotelonline hearings) can be taken forward.

Keywords: Covid pandemic, functioning of the judiciary, access to court/justice, remotelonline hearings, right to a fair trial, detention, European human rights law, European Court of human rights, Court of Justice of the European Union, Croatian Constitutional Court

\section{INTRODUCTION}

The Covid pandemic ${ }^{1}$ has disrupted the daily life of people worldwide, including the work of all state bodies. Restrictions on the freedom of movement, the lockdown measures and social distancing also impacted the functioning of justice systems, including the work of courts. ${ }^{2}$ However, even during the pandemic, judicial institutions were expected to continue to function effectively and to maintain functionality, accountability, transparency, and integrity, ensuring due process and the continuity of judicial activities, including efficient access to justice consistent with the right to a fair trial and other fundamental rights and freedoms. ${ }^{3}$

Access to justice is a fundamental component of the rule of law. ${ }^{4}$ It could be argued that at all times, the access to justice must be ensured, and special attention must be devoted to the access to justice by vulnerable groups who are even more affected by extraordinary situations, such as the Covid pandemic. ${ }^{5}$ Thus, during

For instance, Council of Europe Secretary General, Respecting democracy, rule of law and human rights in the framework of the COVID-19 sanitary crisis: A toolkit for member states, SG/Inf(2020)11, 7 April 2020, p. 2.

2 For instance, Turner, J.I., Remote Criminal Justice, Texas Tech Law Review, Vol. 53, No. 2, 2021, p. 198.

3 Resolution 44/9 (16 July 2020), Independence and impartiality of the judiciary, jurors and assessors, and the independence of lawyers, paras 17-18.

4 See further on the different restrictions and their modalities, European Commission for Democracy through Law (Venice Commission), Report - Respect for Democracy Human Rights and Rule of Law during States of Emergency - Reflections, CDL-PI(2020)005rev, 26 May 2020; Peršak, N., Editorial: COVID-19 and the Social Responses thereto: Penal and Criminological Lessons, Human Rights and Rule of Law Implications, European journal of crime, criminal law and criminal justice, Vol. 28, 2020, pp. 205-216. See also Spano, R., The rule of law as the lodestar of the European Convention on Human Rights: The Strasbourg Court and the independence of the judiciary, European Law Journal, 2021, pp. 2-5.; Lenaerts, K., Federalism and the Rule of Law: Perspectives from the European Court of Justice, Fordham International Law Journal, Vol. 33, No. 5, 2011, p. 1378.

5 See further Kamber, K., Measures related to health issues, Regional online round table The impact of the COVID-19 pandemic on human rights and the rule of law, Strasbourg, 28 April 2020. 
the pandemic, judicial systems were expected to give priority to cases that involved urgency (notably detention cases), but also cases of domestic violence, cases involving elderly people or persons with disabilities, etc. ${ }^{6}$

The different Covid restrictions rendered, in particular, the in-person hearings challenging or impossible. ${ }^{7}$ At the time of the worldwide lockdown in March 2020, many states have temporarily postponed all non-urgent court hearings and/ or sought ways to keep the courts running through means of remote access - online hearings,${ }^{8}$ including via video link or similar substitutes for physical presence (e.g., telephone hearings). ${ }^{9}$ However, in this connection, the critical question is the extent to which these measures have had an adverse impact on the guarantees of the right to a fair trial and the due process in general, notably in detention cases.

The article examines the manner of the administration of justice during the Covid pandemic and its impact on the due process guarantees, ${ }^{10}$ with an emphasis on the effects of remote/online hearings in this context. In Section 2, the article provides a comparative overview of the functioning of the European legal systems during the pandemic. Section 3 looks into the manner in which the two European courts - the European Court of Human Rights ("ECtHR") and the Court of Justice of the European Union ("CJEU") - operated during the pandemic. Section 4 examines the manner in which Croatian courts, including the Constitutional Court, have organised their work during the pandemic. Section 5 analyses the relevant case-law of the ECtHR and the Constitutional Court relating to remote/online hearings. A conclusion is provided in Section 6.

6 CEPEJ Declaration Lessons learnt and challenges faced by the judiciary during and after the COVID-19 pandemic, CEPEJ, Ad hoc virtual CEPEJ plenary meeting, Strasbourg, 10 June 2020, see principle 2 (Access to justice), p.2.

7 Management of the judiciary - compilation of comments and comments by country, CEPEJ, 10 July 2020, accessed 1 April 2021.

8 See further McKeever, G., Remote Justice? Litigants in Person and Participation in Court Processes during Covid-19, Modern Law Review, No. 5, 2020.

9 Courts COVID-19 measures as of 15 April 2020, available at [https://rm.coe.int/courts-covid-19-measures-as-of-15-april-2020/16809e2927], Accessed 1 April 2021.

10 From the perspective of the right to liberty and the right to a fair trial. See further ECtHR's Guide on Article 5 of the European Convention on Human Rights: Right to liberty and security, Strasbourg, 2020; ECtHR's Guide on Article 6 of the European Convention on Human Rights: Right to a fair trial (criminal limb), Strasbourg, 2021. 


\section{FUNCTIONING OF THE EUROPEAN LEGAL SYSTEMS DURING THE PANDEMIC}

\subsection{The functioning of the judiciary}

In response to the Covid outbreak, different European countries have acted differently: some have declared a state of emergency and some others a coronavirus pandemic. The different Covid restrictions impacted the work of courts ${ }^{11}$ as (physical) access to courts ${ }^{12}$ has come under severe restrictions. Some countries closed court buildings fully, others partially, dealing only with "urgent"13 ${ }^{\text {cases. }}{ }^{14}$

The extent to which judges and court staff have been able to operate in person and remotely, especially during the national lockdowns, depended on several factors: the state's response to the pandemic, the regulations imposed by the authorities ${ }^{15}$ and the respective courts' scope and type of competence. ${ }^{16}$ Moreover, it should be noted that not all courts in all countries experienced the same issues so there was a significant variation in how countries have approached the issue of court management. ${ }^{17}$

11 Including delays in proceedings, impact on procedural time limits, and the provision of legal aid services, see Consultative Council of European Judges ("CCJE"), Statement of the President of The CCJE, The role of judges during and in the aftermath of the COVID-19 pandemic: lessons and challenges, CCJE (2020)2, 24 June 2020, p. 2.

12 The CCJE has already emphasised that the rule of law is guaranteed by the fair, impartial and effective administration of justice, and these principles developed by the CCJE, as well as by the Council of Europe as a whole, notably including rights to access to a court and an effective remedy, should be strictly safeguarded during emergency situations in general and a pandemic in particular, Ibid.

13 The International Commission of Jurists ("ICJ") has provided helpful principles to assist in the determination of urgency, see The Courts and COVID-19, International Commission of Jurists (ICJ), 5 May 2020, [https://www.icj.org/wp-content/uploads/2020/05/Universal-ICJ-courts-covid-Advocacy-Analysis-brief-2020-ENG.pdf], Accessed 15 April 2021.

14 For instance, in Croatia, Denmark, Cyprus, France, and Greece, see Coronavirus Pandemic in The EU - Fundamental Rights Implications: With A Focus on Contact-Tracing Apps, Fundamental Rights Agency, Bulletin No. 2, 21 March - 30 April 2020, p. 28.

15 In some jurisdictions, decisions on how to manage courts during pandemic have been taken by the executive authorities, with or without consultation from the judiciary, in some states, measures have been set out in legislation and procedural laws, while others have been determined by the judicial authorities such as judicial councils or by judges themselves, see The Functioning of Courts in the COVID-19 Pandemic: Primer, October 2020, pp. 17-18, [https://www.osce.org/files/f/documents/5/5/469170.pdf], Accessed 15 April 2021.

16 Ibid, p. 5.

17 The legal regulation of court proceedings in the pandemic time, in some legal systems is the part of a broader package of economic measures to mitigate the effects of the COVID-19 epidemic, see for instance Italy's Economic Measures to Mitigate the Effects of COVID-19 (e.g. "Simplification Decree", “The Legislative Decree no. 15", “The Law Decree No. 129/2020"), 18 March 2020, available at https://www.clearygottlieb.com/news-and-insights/publication-listing/italys-economic-measures-to-mitigate-the-effects-of-covid-19, accessed 15 April 2021, or is the part of the regulating the 
At the time of the worldwide lockdown, many European countries have temporarily postponed all non-urgent court hearings, seeking ways to keep the courts ${ }^{18}$ running during the emergency, and turned to remote hearings using online videoconferencing technology and other similar tools as an alternative to in-person hearings in the context of pre-trial and trial proceedings. The experience has shown that there were different approaches to this matter, within, and between different jurisdictions.

However, in general, there were two ways in which countries decided whether the case could proceed remotely:

- Consent of the person - for instance, in Romania, the authorities required a signed consent from the defendant to participate in a remote hearing, as opposed to Germany and Belgium, where the judges had the power to decide on whether to have a remote hearing without the defendant's consent, and

- Type of cases - for instance, initially the Netherlands had put limits on remote hearings, excluding them in cases involving minors or persons with mental disabilities, but these restrictions were later lifted giving judges the discretion to decide on whether to hold hearings remotely. In Spain, remote proceedings were allowed in all criminal cases, except for cases of serious crime, and in Latvia, videoconferencing was used for persons in custody. ${ }^{19}$

Countries where videoconferencing was used in civil and criminal proceedings included: Austria, Croatia, France, Hungary, Ireland, Kazakhstan, Portugal, Serbia, Slovenia, Sweden, and the United Kingdom. ${ }^{20}$

Furthermore, different courts in different jurisdictions have conducted remote proceedings using different online platforms ${ }^{21}$ (or by telephone conference call,

functioning of courts and communication between courts and parties, like in Germany, see Act to Mitigate the Consequences of the COVID-19 Pandemic under Civil, Insolvency and Criminal Procedure Law of 27 March 2020, (Gesetz zur Abmilderung der Folgen der COVID-19-Pandemie im Zivil-, Insolvenz- und Strafverfahrensrecht, BGBl. I Nr. 14, 27. 3. 2020).

18 As a Declaration of the European Commission for the Efficiency of Justice ("CEPEJ") stressed "The key standards underpinning the operationalization of the courts must continue even during times of emergency", see note 6. See also Ritscher, C., COVID-19 and International Crimes Trials in Germany, Journal of International Criminal Justice, 2021, pp. 1-4.

19 Beyond the Emergency of the COVID-19 Pandemic: Lessons for Defence Rights in Europe, June 2020, Fair Trials, p. 14., [https://www.fairtrials.org], Accessed 16 April 2021.

20 See further about the videoconferencing and remote hearing, problems faced with IT solutions, and conditions and criteria for the use of remote hearings, op. cit., note 15, pp. 22-24.

21 The concern about the proceedings via Zoom platform in the context of personal data before the Family Court in England and Wales has been stressed in the Council of Bars and Law Societies of Europe (CCBE) Guidance on the use of remote working tools by lawyers and remote court proceedings, 2020, p. 6., available at [https://www.ccbe.eu]. Furthermore, there are other issues, for instance, in relation to 
for instance in France). On the other hand, some hearings were held in a "hybrid" format, where some participants participated in person and others remotely. ${ }^{22}$

Although many courts have recently reopened, due to the measures taken during the pandemic, they are now facing backlog. ${ }^{23}$ At the same time, in some states (e.g. Belgium, Hungary and Spain), the authorities have made proposals to continue to use remote hearings after the pandemic ${ }^{24}$ as a solution for the time and cost-effective functioning of courts. ${ }^{25}$ However, it would not appear that these measures could be taken without giving a due consideration for the implications on the right to a fair trial and other due process guarantees associated with the physicial presence of an accused in the proceedings. ${ }^{26}$

The Covid pandemic has also brought to the fore the challenges that courts faced for years in several states, especially financial constraints and inefficient procedures. Some states during the pandemic saw a shift in power from the judiciary to the executive. ${ }^{27}$ However, the positive effect is that the pandemic has created an incentive for countries to review and reform judicial systems. ${ }^{28}$

The challenges to the work of judges and prosecutors, ${ }^{29}$ and other legal professionals, are particularly demanding in the context of a pandemic. They had to adapt to

equality of arms: a disadvantage to parties lacking access to IT, the effect of poor internet speeds, the difficulty for a judge to effectively assess the credibility of a witness without seeing the witness in the flesh, the problems with the security of remote connections, etc., Ibid., p 7.

22 See an interesting example of criminal proceedings in Scotland, Ibid, p. 8.

23 See [https://www.fairtrials.org/news/], Accessed 16 April 2021.

24 Susskind, R., Online Courts and the Future of Justice, Oxford University Press, Oxford, 2019.; Legg, M., The COVID-19 Pandemic, the Courts and Online Hearings: Maintaining Open Justice, Procedural Fairness and Impartiality, Federal Law Review, Vol. 49, 2021, pp. 20-46.

25 For instance, in June 2020, Poland introduced remote pre-trial detention hearings by means of a permanent modification of the Criminal Code of Procedure; in Hungary, a government decree was issued in March 2020, making remote hearings obligatory when procedural acts could not be postponed, [https://www.fairtrials.org/news/impact-covid-19-rule-law-hungary-and-poland], Accessed 16 April 2021.

26 Op. cit., note 22.

27 For instance, in Albania, the lack of a functioning Constitutional and Supreme Court has hampered effective oversight of urgent legislation, [https://ec.europa.eu/neighbourhood-enlargement/sites/near/ files/albania_report_2020.pdf], and [https://ec.europa.eu/commission/presscorner/detail/en/COUNTRY_20_1794], Accessed 16 April 2021.

28 See Global Prison Trends 2020. Alternatives to Imprisonment, Penal Reform International, [https://www. ohchr.org/EN/NewsEvents/Pages/DisplayNews.aspx?NewsID=25819\&LangID=E], and [https:// idpc.net/publications/2020/05/global-prison-trends-2020], Accessed 15 April 2021.

29 See further about the work of prosecutors in a pandemic, Consultative Council of European Prosecutors (CCPE) Opinion No. 15 (2020): The role of prosecutors in emergency situations, in particular when facing a pandemic, Strasbourg, November 2020. 
the rapidly changing circumstances linked to the different phases of the pandemic. It is thus not surprising that there might have been different views about the relevant priorities, which mandated for the stablishment of a dialogue between all judicial stakeholders, such as associations of judges, bar associations, etc.

However, it is reasonable to assume that all of them agreed over the necessity of preventing the propagation of the virus. Indeed, the courts took the necessary measures to that effect, such as disinfecting the building, wearing protective masks, measuring the temperature of all visitors, etc., and where possible, court staff who were at risk worked remotely or in shifts.

\subsection{Lawyer's response to the pandemic}

Exceptional circumstances which require court closures, such as the Covid pandemic or earthquakes (like those experienced in recent times in Croatia), ${ }^{30}$ seriously limit various defence rights, especially the right of access to a lawyer. ${ }^{31}$ Remote communications - in courts, police stations and prisons - represented a challenge for lawyers and defendants to interact with each other and to have confidential and effective consultations. ${ }^{32}$

According to the first reports relating to the effects of the Covid pandemic, lawyers experienced difficulties in being able to provide assistance in the context of remote hearings. For instance, in the Netherlands and Spain, confidential lawyer-client communication was not possible for lawyers during hearings where the defendant was only allowed to appear via videoconference. In France, lawyers complained about the inability to participate in detention hearings because of a lack of videoconferencing equipment in some courts, and in Poland and Hungary concerns were raised about the confidentiality of communication between lawyers and de-

30 Earthquake occurred in Zagreb on 22 March 2020, which destroyed numerous judicial and penal facilities. The earthquake hit the hardest the Zagreb County Court, the Zagreb Commercial Court and the State Attorney's Office, so parts of the courts that could not be used moved to the locations of the Zagreb Municipal Criminal Court and to another location, see Markušić, S. et al., The Zagreb (Croatia) M 5.5 Earthquake on 22 March 2020, [https://res.mdpi.com/d_attachment/geosciences/geosciences-10-00252/article_deploy/geosciences-10-00252-v2.pdf], Accessed 16 April 2021.

31 See further about the right to effective assistance of counsel, Babcock, E.; Johansen, K., Remote Justice? Expanding the Use of Interactive Video Teleconference in Minnesota Criminal Proceedings, William Mitchel Law Review, Vol. 37, No. 2, 2011, p. 679.

32 There are numerous examples of courts in Croatia which limited its work to varying degrees, which could be conclude by following the courts' websites, and which for parties and parties representatives are unfavourable, because each court has its own restriction determined by each president of the court individually, see for instance the Municipal Civil Court in Zagreb, [http://sudovi.pravosudje.hr/ ogszg/], Zagreb County Court [https://sudovi.pravosudje.hr/zszg/], Accessed 15 April 2021. 
fendants, especially when prisons guards are present. ${ }^{33}$ In the United Kingdom, lawyers noted that some platforms used by the courts did not allow them to speak with their client at all once the hearing had started, ${ }^{34}$ and Portugal enacted restrictions on access to a lawyer for persons in prison.

Furthermore, some states did not allow access to the case files, which limited the possibility of the defence to prepare its case. In addition, there was a big disparity between the European countries' capacity to arrange for the filing of submissions to the court by mail or otherwise electronically.

All these restrictions indicate that lawyers faced many difficulties to preform their tasks during the pandemic. It was therefore critical, as already stated above, to ensure cooperation between all legal professions, including lawyers. The legal professionals must communicate when adopting any measures ${ }^{35}$ in the context of the pandemic. ${ }^{36}$ This is important in order to take into account all possible effects and impacts of adopted measures and to avoid conflict and disagreements within the judicial systems. ${ }^{37}$ Thus, measures and protocols adopted in relation to courts need to be communicated effectivelly to all relevant persons, including lawyers and their associations. ${ }^{38}$

\subsection{The conditions of detention during the pandemic}

Both detainees and the prison staff were particularly vulnerable during the pandemic: detention facilities often provide limited access to sanitation and health facilities, and are overcrowded, making physical distance and isolation almost impossible, and thus increase the possibility of infection.

33 See note 25 .

34 Op. cit., note 21.

35 See further about the question of decision-making powers and responsibilities, especially who has the authority for deciding how the judicial system should respond to the pandemic at various stages, see op. cit., note 15 , pp. 12-13.

36 As the CEPEJ stressed, "Greater consultation and coordination with all justice professionals (including lawyers, enforcement agents, mediators and social services) will help to ensure a good level of access to justice"; op. cit., note 6 .

37 For instance, lawyers in Greece who went on strike after the reopening of some courts, op. cit., note 15, p. 11. On the other hand, The Macedonian Young Lawyer Association and the Kosovo Law Institute's Free Legal Aid Center offered legal aid during the lockdown, for more see op. cit., note 15, p. 19.

38 For instance, see the communication between the Croatian Bar Association, Minister of Justice of the Republic of Croatia and the President of the Supreme Court of the Republic of Croatia, available at [http://www.hok-cba.hr/hr/obavijest-o-poduzetim-radnjama-hok-vezano-uz-covid-19-i-potres-u-zagrebu], Accessed 16 April 2021. 
To reduce the risk of infection in places of detention, different measures were introduced, such as limited visits by lawyers and families. ${ }^{39}$ This, in turn, limited the rights of detainees to maintain contact with their families, which is their right guaranteed under Article $8 \mathrm{ECHR},{ }^{40}$ and, as noted above, to mount an effective defence in the pending legal proceedings.

In addition, different countries across the European Union face a long-standing crisis of prison overcrowding, which is partially due to the excessive use of pretrial detention. ${ }^{41}$ During the pandemic, most States adopted measures to reduce the prison population (for instance by early/temporary releases) ${ }^{42}$ and some of them temporarily delayed the execution of prison sentences. Adopted measures and efforts certainly led to the reduction in prison population in many European countries. However, there are concerns over the 'boomerang' effect after the crisis is over. ${ }^{43}$ According to the first reports, these concerns do not appear to be misplaced. ${ }^{44}$

\section{FUNCTIONING OF THE TWO EUROPEAN COURTS (THE ECTHR AND THE CJEU) DURING THE PANDEMIC}

Just as all other courts, the two European Courts, have taken measures to adapt their activities in response to the Covid pandemic, including by postponing physi-

39 These measures have had consequences on the detainees, in particular on their mental health. There are reports of suicides, for instance in the UK, see further European Prison Observatory, COVID-19: What is happening in European prisons? Update \#9, 5 June 2020, p.8., available at [http://www.prisonobservatory.org/index.php?option=com_content\&view=article\&id=32:covid-19-what-is-happening-in-european-prisons\&catid=7\&Itemid=101], Accessed 16 April 2021.

40 Khoroshenko v Russia [GC] (2015).

41 Prison overcrowding is a problem in the several EU Member States, including Belgium, Romania, Greece, and Hungary, see Prison Studies, Highest to Lowest - Occupancy level (based on official capacity), available at [https://www.prisonstudies.org/highest-to-lowest/occupancy-level?field_region_taxonomy_tid=All], Accessed 15 April 2021, see also Green Paper Strengthening mutual trust in the European judicial area - A Green Paper on the application of EU criminal justice legislation in the field of detention, available at [https://eur-lex.europa.eu/legal-content/EN/ALL/?uri=celex:52011DC0327], Accessed 16 April 2021.

42 Op. cit., note 39. See further about the prison measures, Fair Trials, op. cit., note 26.

43 See further about the success of the different measures adopted to reduce prison populations in many EU Member States, and a failure to reduce the number of detainees, Beyond the Emergency of the COVID-19 Pandemic: Lessons for Defence Rights in Europe, June 2020, Fair Trials, pp. 42-43, see note 19., accessed 16 April 2021.

44 See Aebi M.F.; Tiago, M.M., Prisons and Prisoners in Europe in Pandemic Times: An evaluation of the medium-term impact of the COVID-19 on prison populations, Council of Europe Annual Penal Statistics, Strasbourg, Lausanne, December 2020. 
cal hearings, enhancing online hearing capabilities, prioritising urgent cases and extending the procedural time-limits.

The ECtHR took the decision to hold online hearings with the exclusion of the public. However, as will be discussed in more detail further below, it managed to ensure, through the use of information tecohnology, the public character of those hearings. ${ }^{45}$

The ECtHR took several other exceptional measures during the national lockdown in France between 16 March and 10 May 2020. The President of the ECtHR extended the six-month time-limit for the lodging of applications based on force majeure for three months until 15 June 2020. The time limits allotted in pending proceedings were also extended for a further two month period from 16 April 2020.

The ECtHR has been able to fulfill its public service mission during the national lockdown period by ensuring continuity of its core activities, handling urgent cases, and receiving and allocating applications to the relevant judicial formations. The Grand Chamber, Chambers Committees, and single judges continued to examine cases by written procedures. Most of the Registry staff and all judges during the national lockdown continued to deal with the cases by written e-mail procedure. The ECtHR therefore managed to continue to function and deal with cases expeditiously. ${ }^{46}$ A significant achievement was also the organisation of the Grand Chamber hearings, which took place by videoconference which could be viewed online. ${ }^{47}$ In this way, the ECtHR was able to continue to carry out its mission and ensure the public nature of the hearings through webcasting. ${ }^{48}$

45 Because of the Covid pandemic and until further notice, hearings at ECtHR are not open to the public and may be held by videoconference, by decision of the President of the Grand Chamber or the relevant Chamber, see notification available at [https://www.echr.coe.int/Pages/home.aspx?p=hearings\&c=], Accessed 1 April 2021.

46 During the national lockdown more than 5400 applications were processed and because of that activity, the total stock of pending cases has remained stable; see The ECHR and the Pandemic - Rule of Law as the Lodestar of the Convention System, speech by Robert Ragnar Spano, President of the ECtHR, held on the Seventh Regional Rule of Law Forum for South-East Europe, 16 and 17 October 2020, author participation via Zoom platform.

47 This was a major technical challenge for the Court, but it manages to hold three online hearings during the pandemic; all online (public) hearings are available at [https://www.echr.coe.int/Pages/home. aspx?p=hearings\&c=], Accessed 2 April 2021; see also the first videoconference on the execution of ECtHR judgments held on 29 January 2021; the Execution Department organised the first videoconference with the Belgian authorities, including the Office of the Government Agent to the ECtHR and representatives of the Ministry of Justice, available at [https://www.coe.int/en/web/human-rights-ruleof-law/-/belgium-videoconference-on-the-execution-of-ecthr-judgments], Accessed 2 April 2021.

48 Op. cit., note 9., p. 4. Regarding the webcasting of court sessions, in normal conditions, webcasting is being used to reach a wider audience and encourage a broader interest in the aspects of public life 
For its part, the $\mathrm{CJEU}^{49}$ has also been obliged to change its working arrangements due to the Covid pandemic. ${ }^{50}$ These changes concerned the conduct of the written phase $^{51}$ of the proceedings and, in particular, the extension of certain time limits ${ }^{52}$ for the filing of parties's statements or observations as well as the conduct of the oral phase of the proceedings. ${ }^{53}$

The procedural time limits continued to run despite the pandemic and the parties had to comply with those time limits, without prejudice to the possible application of the Protocol (no 3) on the Statute of the Court of Justice of the European Union ("the Statute") Article 45 paragraph 2.54

All necessary measures were taken to ensure that the hearings took place under optimal conditions, from both a logistical and sanitary perspective, but the holding and conduct of the hearings remained dependent on the decisions of the national authorities to combat the transmission of the coronavirus. If it was completely impossible for a party to travel to Luxembourg, it was allowed, under certain conditions, to attend a hearing by videoconference. To ensure efficient conduct of

touched upon by courts. Accordingly, when it comes to an emergency situation, webcasting may be even more justified in order to expressly demonstrate that justice is being performed openly and in public.

49 The number of cases resolved for the first quarter amounted to the same as in 2019. Procedural measures compensated for the incapacity to hold hearings. All hearings and pleadings were postponed to a later date; 60 cases were considered urgent and one Urgent Preliminary Request was kept in progress for which the chamber has decided to waive the hearing and to put questions to the parties for written answers.

50 See further about the working conditions of the CJEU Popotas, C., COVID-19 and the Courts. The case of the CJEU, Access to Justice in Eastern Europe, Vol. 2-3, No. 7, 2020, pp. 160-171.

51 Written questions to the parties replaced the debates that would normally take place in courtrooms. Deliberations amongst judges were in the first period conducted through written procedures via secure email, and later replaced by secure videoconferencing.

52 On 19 March 2020, the CJEU temporarily changed the working arrangements for its two constituent courts: The Court of Justice and the General Court. Court of Justice time limits prescribed in all non-urgent ongoing proceedings was extended by one month. Time limits to be fixed by the registry of the CJEU were also extended by one month. Hearings before the Court of Justice listed to take place before 3 April 2020 were postponed. Urgent cases before the General Court were dealt with as a matter of priority, and time limits were fixed by the registry of the CJEU.

53 These measures remain subject to frequent modifications depending on how the health crisis evolves, see [https://curia.europa.eu/jcms/jcms/p1_3012066/en/], Accessed 3 April 2021.

54 See Protocol (no 3) on the Statute of the Court of Justice of the European Union, Official Journal of the European Union, C 202/210, Article 45 paragraph 2: "No right shall be prejudiced in consequence of the expiry of a time limit if the party concerned proves the existence of unforeseeable circumstances or of force majeure". See further about procedural time limits COVID-19 - Information - Parties before the Court of Justice, [https://curia.europa.eu/jcms/jcms/p1_3012066/en/], Accessed 3 April 2021. 
the hearings, particularly from a linguistic perspective, the parties' representatives were requested to inform the Registry whether they would attend or not a hearing.

To facilitate communication with the parties, the courts of the Member States and the parties' representatives were strongly encouraged to become familiar with the CJEU online system (e-Curia) and to have an e-Curia account, which is a secure application and allows procedural documents to be filed and served electronically in cases brought before the CJEU.

Following the decisions of the Court of Justice and the General Court gradually to resume hearings with effect from 25 May 2020, the strictest sanitary measures ${ }^{55}$ have been adopted (in compliance with the laws adopted by the Luxembourg authorities) to allow hearings to proceed under the best possible conditions.

\section{FUNCTIONING OF THE LEGAL SYSTEM IN CROATIA DURING THE PANDEMIC}

\subsection{The functioning of the judiciary}

The Croatian government did not declare a state of emergency but declared a coronavirus pandemic on 11 March 2020. However, in Croatia, not only the Covid pandemic, but also the earthquakes in Zagreb, ${ }^{56}$ significantly affected the functioning of courts, ${ }^{57}$ especially due to the difficulties in holding hearings in person before the trial courts.

The recommendations of the Ministry of Justice ${ }^{58}$ and decisions of the President of the Supreme Court, ${ }^{59}$ as well as the decisions of presidents of the lower courts, regulated the functioning of courts ${ }^{60}$ in Croatia. However, notwithstanding these recommendations, the courts have limited their work to varying degrees.

\footnotetext{
55 Those measures concern access to the institution's buildings and the rules that must be complied with while moving around within them, and the arrangements for the hearing itself, which have been adapted in response to the current exceptional circumstances.

56 See further about earthquakes in Croatia, [https://www.pmf.unizg.hr/geof/seizmoloska_sluzba/o_zagrebackom_potresu_2020?@=1lrg6], Accessed 16 April 2021., see also note 30.

57 See further about restrictions on court working in Croatia, CCBE Questionnaire Restrictions on court working, Croatia, pp. 13-15., available at [https://www.ccbe.eu], Accessed 2 April 2021.

58 See further about the recommendation of the Ministry of Justice, [https://mpu.gov.hr], [http://www. hok-cba.hr], Accessed 2 April 2021.

59 See further about the decision and the recommendation of the President of the Supreme Court, [http://www.vsrh.hr], Accessed 2 April 2021.

60 See further about the functioning of the Zagreb Municipal state Attorney's Office, the State Attorney's Office of the Republic of Croatia, and the Office for the Suppression of Corruption and Organized
} 
On 17 March 2020, the Ministry of Justice issued a recommendation ${ }^{61}$ applicable during the Covid pandemic in order to protect the health of all judicial staff and parties to the proceedings. On 20 March 2020, ${ }^{62}$ the President of the Supreme Court issued a recommendation to the Presidents of the High and County Courts according to which in every situation the technical means of remote communication available to judges and courts, including when communicating within the court (e-mail, video link, etc.), should be used. ${ }^{63}$ Videoconferencing (online hearings), as up to then a non-common practice, were also introduced concerning the detention proceedings. ${ }^{64}$

Furthermore, lawyers, court experts, bankruptcy trustees and legal entities were able to communicate electronically with the courts via the system of e-Communication. ${ }^{65}$ The e-Communication system provided lawyers, citizens, and other users access to the content of all documents if they had a content entered in the e-Case system (court case management system).

According to the decision of the President of the Supreme Court, most of the courts in Croatia conducted hearings remotely, especially in urgent cases - detention cases and some criminal and civil cases. The ability of courts in Croatia to conduct hearings remotely was possible on the basis of the existing laws. In

Crime for instance in Coronavirus pandemic in the EU - Fundamental Rights Implications, Croatia, Centre for Peace Studies, Human Rights House, 2 July 2020, p. 7.

${ }_{61}$ The Minister of Justice made the following recommendations regarding the prevention of the transmission and suppression of the coronavirus epidemic: 1 . The judicial authorities continue to operate and carry out all urgent procedures and actions with appropriate security controls; 2. Hearings and other non-urgent actions are adjourned for 14 days; 3 . Employers allow to work from home in business locations where possible; 4. Electronic communication should be conducted in dealing with parties and all participants in the process, wherever possible, see [http://www.hok-cba.hr/hr/preporuke-ministarstva-pravosuda-i-vrhovnog-suda-rh-u-vezi-rada-pravosuda-i-epidemije-koronavirusa], Accessed 15 April 2021.

62 Letter no. Su-IV-125/2020-5 of 20 March 2020.

63 Furthermore, the President of the Supreme Court by Decision no. Su-IV-125/2020-50 of 31 March 2020 ordered the presidents of the departments of that court to determine the work schedule of judges and legal advisers in the court department and court registry to conduct court business in those matters, related to non-delayed proceedings, such as urgent criminal cases related to time limits, which include pre-trial detention.

64 Criminal Procedure Act, Official Gazette, Nos. 52/08, 76/09, 80/11, 121/11, 91/12, 143/12, 56/13, $145 / 13,152 / 14,70 / 17$ and $126 / 19$, contains provisions on actions that can be taken by the application of appropriate audio-visual devices, Article 129. para 2.

65 E-Communication enables participants in court proceedings to submit submissions to the courts electronically, receive court documents in a secure electronic mailbox and remotely inspect court cases; see [https://usluge.pravosudje.hr/komunikacija-sa-sudom/], Accessed 16 April 2021. See also notifications of the Ministry of Justice, available at [https://pravosudje.gov.hr/vijesti/ekomunikacija-priblizava-sudove-gradjanima/21945], Accessed 16 April 2021. 
civil proceedings, it has been possible to hold remote hearings since September 2019, as provided for in Article 115 of the Civil Procedure Act, ${ }^{66}$ and in criminal proceedings, the same was possible under Article 129 para 2 of the Criminal Procedure Act. ${ }^{67}$

The courts in Croatia started to function in accordance with the recommendation of the President of the Supreme Court ${ }^{68}$ as of 11 May 2020. At present, the work of courts has almost completely normalised, and presidents of the courts had in the meantime issued decisions to continue to work in full capacity with further adherence to the general preventive measures (maintaining social distance, hand disinfection, wearing masks, etc.).

The courts currently regularly hold trials in all cases, but in so-called "new" conditions, which reflect the recommendations issued by the President of the Supreme Court for the prevention of the spread of the virus. In particular, there are two models of organisation of the work of courts during the pandemic: model A and model B.

According to model A, the first-instance courts need to act in all types of cases by complying with certain restrictions in order to reduce the number of persons in the court premises and they must ensure conditions for a physical distance between persons of at least 2 meters. For this purpose, the court presidents need to take a close control over the scheduling of the courtroom use. In this mode, it is also recommended to use audio-video conferences as much as possible, for instance, if a person deprived of liberty should appear at a court hearing, an audiovideo conference should be used wherever possible, and if this cannot be arranged, the hearing must be scheduled well in advance. In relation to pre-trial detention, including the judicial control of the situation in places of detention, it is recommended to use the video link where possible.

With regarding to the appeal courts, the presidents of these courts must take charge of the court schedules and court sessions should be held via an audio-video

66 Civil Procedure Act, Official Gazette, Nos. 53/91, 91/92, 112/99, 88/01, 117/03, 82/05, 02/07, 84/08, 96/08, 123/08, 57/11, 25/13, 89/14 28/13 and 70/19.

67 See note 53.

68 The President of the Supreme Court recommended the presidents of all courts to check whether the courts have courtrooms of sufficient size to hold hearings with respect to physical distance, to draw up a schedule for the use of these courtrooms and to check the ability to connect multiple rooms in the court via video link to hold hearings with a larger number of participants. Such hearings would refer to "old" cases and those cases that are already being finalised, regardless of the court department and branch of the law. The presidents of the courts will therefore be those who will determine the measures that will gradually increase the volume of work in each court, see notification of the Supreme Court, available at [http://www.vsrh.hr], Accessed 16 April 2021. 
conference. Where the latter is not possible, the court sessions must be held so that there is at least a physical distance of at least two metres between persons.

According to model B, the first-instance courts take actions only in urgent cases. Hearings in all other cases are postponed for fourteen days, and the audio-video conferencing should be used as much as possible. The appeal courts are expected to operate in a similar way as described above for model A.

As of 3 November 2020, the presidents of all courts are expected to organise the work according to model $\mathrm{A}$, and according to model $\mathrm{B}$ only if there is an unfavourable development of the epidemiological situation. To switch to Model B, the president of each court must request an approval of the President of the Supreme Court. ${ }^{69}$

Regardless of the model according to which the work is organised, the President of the Supreme Court requested the president of all courts to ensure the implementation of all epidemiological measures, communicate with the participants exclusively electronically, and deliver mail using email services and, where possible, limit the admission of parties in the land registry department or court register.

\subsection{Lawyer's response to the pandemic}

It should be noted that lawyers and the Croatian Bar Association ("CBA") continued to operate effectively and to keep contact with the relevant courts and other judicial authorities. ${ }^{70}$ In addition, the CBA established the Crisis Staff of the CBA to take urgent intervention measures in cooperation with all competent bodies in Croatia to mitigate all negative consequences of the events that significantly affected the legal service and the position of lawyers. ${ }^{71}$ Furthermore, on 18 March 2020, the CBA decided to waive the membership fee for all members of the CBA for April 2020, while it was up to the local branches to make decisions with respect to the membership fees due to them.

On the same date, the CBA sent to the Ministry of Justice a draft Act on the Intervention Measures in the area of judicial and administrative proceedings due to the Covid pandemic. ${ }^{72}$ This draft dealt, in particular, with the following: the

69 See further about two models of organisation of the work of courts during the pandemic, [http://www. vsrh.hr], Accessed 16 April 2021.

70 Notices of action taken by CBA regarding Covid-19 and the earthquake in Zagreb, see note 30.

71 Ibid.

72 The CBA referred to similar measures taken in other EU Member States, adopted for the purpose of preventing the spread of infection caused by COVID-19 disease and the need to enable the proper functioning of courts, state bodies, local and regional self-government bodies of public authorities. For 
interruption of deadlines; the manner of work of courts; the regulation of hearings via audio-video link; the suspension of deadlines in the administrative proceedings; the manner of work of public bodies; measures in the field of execution of criminal sanctions; and the termination of accumulation of default interest in the judicial and administrative proceedings.

Furthermore, immediately after the earthquake, in which a significant number of law offices had been damaged and as a result of which certain lawyers had been barred from entering their offices due to a danger of collapsing, the CBA once again addressed the Ministry of Justice, the Ministry of Finance and the Supreme Court seeking assistance and intervention.

In addition, it should be noted that during the national lockdown, lawyers were not given any special privilege of free movement. However, in urgent proceedings (such as the proceedings on pre-trial detention, family proceedings, psychiatric internment), lawyers were able to obtain a permit that allowed them to move outside their place of residence. ${ }^{73}$ Moreover, there were no possibilities of consulting lawyers through videoconferencing. ${ }^{74}$

\subsection{The conditions of detention during the pandemic}

As regards the prison system, attention has been given to the prevention of contagion, and precautionary measures, such as increased hygiene of persons and premises, disinfection of facilities, and additional supply of the protection equipment. ${ }^{75}$ In addition, more frequent outdoor activities were organised, and every prison facility has ensured specific rooms to isolate persons with the Covid symptoms. Isolation areas of a greater capacity were also put in place in prisons. ${ }^{76}$

instance, Slovenia adopted the Act on Interim measures in relation to judicial, administrative and other public law cases in order to control the spread of the infectious disease SARS-CoV-2 (COVID-19) - Act on Interim Measures in Relation to Judicial, Administrative and Other public law matters for the control of the spread of the infectious disease SARS-CoV-2 (COVID-19), Official Gazette of the Republic of Slovenia, No. 36/20. The Act was published on 28 March and entered into force on 29 March 2020.

73 See CCBE Replies to the questionnaire on the implications of the COVID-19 (urgent issues), 18/06/2020, pp. 2-3., available at [https://ccbe.eu/], Accessed 16 April 2021.

74 See Council of Bars and Law Societies of Europe (CCBE) Survey: Exchange of experiences and best practices between bar, Croatia, p. 14.

75 See more about measures and activities in the prison system aimed at preventing the spread of coronavirus, available at [https://www.koronavirus.hr/mjere-i-aktivnosti-u-zatvorskom-sustavu-usmjerene-prevenciji-sirenja-korona-virusa/307]; see further [https://www.hzjz.hr/wp-content/uploads/2020/03/ Postupnik-Zatvorski-sustav.pdf], Accessed 1 April 2021.

76 See CEPEJ Compilation - Comments for Croatia, op. cit., note 7. 
The right of prisoners to receive visitors has been limited, but that is changing depending on the development of the pandemic. According to the measures initially introduced in 2020, the right of prisoners to receive visitors from a family members and others has been temporarily restricted, in particular from 14 March 2020 until 1 April 2020, but they could contact their lawyers by telephone, and only exceptionally receive visitors. From 1 April 2020 this measure has not applied to visits by lawyers representing persons deprived of their liberty in criminal and other proceedings. ${ }^{77}$ Videoconferencing with the competent courts has been intensified and the possibility of organising video visits to prisoners has been broadened. ${ }^{78}$

\subsection{The functioning of the Constitutional Court}

The Constitutional Court of the Republic of Croatia ("Constitutional Court") has continued to operate during the pandemic in accordance with the recommendations of the Croatian Institute of Public Health and the National Civil Protection authority (Stožer civilne zaštite) ${ }^{79}$ as well as the Ministry of Justice and internal organisational measures. ${ }^{80}$ The Court took several exceptional measures during the national lockdown.

In March 2020, the Constitutional Court ceased to receive submissions directly from the parties at its premises. The submissions initiating or proposing the initiation of the proceedings, could be sent to the Constitutional Court by mail, while other submissions by e-mail and by fax.

Furthermore, the Court informed the parties and their representatives that its decisions would be published immediately on the website, while they would be sent in writing to the parties or their representatives when the conditions were met. The Constitutional Court also issued a decision temporarily allowing the applicants to institute proceedings (a constitutional complaint and an appeal against the decisions of the National Judicial Council), by submitting it by e-mail and fax. While these measures were later eased, upon the favourable developments of the epidemiological situation, the Court kept the obligation to follow some of the general health care measures listed in the earlier recommendations, such as physi-

77 All information on the situation in the prison system as well as other measures are available on the website of the Ministry of Justice and Administration, [https://mpu.gov.hr/], accessed 2 April 2021.

78 Op. cit., note 63., pp. 13-14.

79 All Notifications and decisions regarding the pandemic situation of the Constitutional Court are available at [www.usud.hr].

80 Constitutional Court has delivered organisational measures related to the organisation of its operating, which varied according to the situation related to the COVID-19 pandemic. All notices are available at [www.usud.hr], Accessed 16 April 2021. 
cal distancing, hygiene measures, disinfection, wearing of a protective mask upon arrival and stay at the Court's premises.

The Constitutional Court also delivered organisational measures related to the organisation of its work, which varied depending on the situation related to the Covid pandemic. ${ }^{81}$ In particular, during the national lockdown, all Chambers ${ }^{82}$ and all judges continued to examine cases by a written procedure and by videoconferencing. In this way the work of sessions, expert meetings, and chambers continued. It could therefore be said that the Constitutional Court has been working in continuation and fulfilling its mission of protecting human rights and its role as the guardian of the Constitution, adapting its work to the conditions caused by the Covid pandemic, but also the earthquakes that have hit Zagreb.

\section{SELECTED EUROPEAN AND CROATIAN CASE-LAW ON THE EFFECTS OF THE PANDEMIC AND THE ISSUE OF REMOTE HEARINGS}

\subsection{The ECtHR case-law}

The ECtHR case-law concerning the remote/online hearings, in general and in the context of the Covid pandemic, is scarce. ${ }^{83}$ However, in its case-law the EC-

81 Several phases of organising the functioning of the Constitutional Court were observed. During the first phase of the Covid measures, in a time of the national lockdown from 16 March to 4 May 2020, the staff was invited to work remotely, while accesses to the Court premises were permitted for halfstaff in view of dealing with issues that could not be handled at a distance. All judges and all Chambers, as well as all legal advisers, continued to work and to have virtual meetings via the internet platform during the remote work period on a regular schedule. The second phase lasted from May 4 to 1 June 2020, following favourable situation regarding the epidemiology and easing of measures, in which the work of staff was organised in such a way that half of the staff was present at the court premises each week, given compliance with epidemiological measures, while all judges were working from the court premises. On 1 June 2020, the Constitutional Court continued its work regularly in accordance with epidemiological measures (maintaining social distance, hand disinfection, wearing masks, etc.) and this third phase lasted until 26 October 2020. The fourth phase began on 26 October 2020 by organising work in shifts at the Court and from home (where possible) with participation in sessions and expert meetings through an online platform. Since 1 December 2020, new organizational measures have been in force related to the organization of sessions and expert meetings held according to the regular schedule. Thus, all expert meetings and sessions of the Court have been held online, the judges participate via the platform from the Court premises and legal advisers participate via the platform from the Court premises or home, depending on the working schedule.

82 Chambers for deciding on constitutional complaints, Chambers ruling on requirements for deciding on constitutional complaints, Chambers for electorate disputes and Chambers for deciding on appeals against decisions on dismissal from judicial office and decisions on the disciplinary responsibility of judges.

83 To date (10 May 2021), the ECtHR has in total decided three cases concerning the effects of the Covid pandemic, none of which specifically dealt with the issue of online hearings: (1) Le Mailloux v France 
tHR did provide certain guidance criteria for the authorities' recourse to online hearings. These criteria, although developed in the context of an ordinary situation where the recourse to online hearings is just another procedural facility in the hands of the authorities, undoubtedly also bear relevance for any recourse to online hearings in the exceptional circumstances of the Covid pandemic, where online hearings were used due to necessity.

According to the ECtHR case-law, the personal presence of an accused in the proceedings should be taken as the rule. Indeed, the ECtHR has explained that an oral, and public, hearing is a "fundamental principle" of the right to a fair trial under Article 6 ECHR. This principle is of a particular relevance in the criminal context where an accused has the right to have her case "heard" by the relevant court. This means, more specifically, that the accused is entitled, inter alia, to give evidence in her defence and to hear the evidence against her/him, as well as to examine and cross-examine the witnesses. ${ }^{84}$

In practice, the exercise of the right to an oral hearing implies the physical presence in the proceedings. This is particularly relevant for the first-instance proceedings where, as the ECtHR stressed, the exercise of different Article 6 guarantees - such as those under sub-paragraphs (c), (d) and (e) of paragraph 3 that guarantee the right "to defend himself in person", "to examine or have examined witnesses" and "to have the free assistance of an interpreter ..." - require the personal presence of the accused. ${ }^{85}$ On the other hand, in the appeal proceedings, the personal attendance of the accused is not of the same crucial significance. In that context, different considerations are relevant for deciding whether the Article 6 requirements have been complied with, notably, the special features of the proceedings involved (whether the issues of facts and/or law are examined); the manner in which the proceedings have been conducted as a whole and what is the role of the appellate court in the overall conduct of the proceedings. ${ }^{86}$

Similar considerations to those under Article 6, concerning hearings on the merits of a criminal case, also apply in the pre-trial detention context under Article 5 ECHR. In this connection, it should firstly be noted that any person deprived of liberty in the context of the criminal proceedings must be "physically brought be-

(2020), concerning allegations of inadequate measures taken to address the pandemic; (2) Feilazoo $v$ Malta (2021), concerning an issue of prison conditions; and (3) Fenech v Malta (2021), which will be analysed below.

${ }^{84}$ Jussila v Finland [GC] (2006), par. 40.

85 Sanader v Croatia (2005), par. 67. It should be noted, however, that Article 6 ECHR does not exclude, under certain conditions, the possibility to hold hearings in absentia: see further Sanader, par. 68-74.

86 Hermi v Italy [GC] (2006), par. 60; Zahirović v Croatia (2013), par. 54. 
fore a judicial officer promptly" pursuant to Article 5(3) ECHR. This is important as it guarantees protection against arbitrary behaviour by the authorities, incommunicado detention and ill-treatment. ${ }^{87}$

Moreover, the ECtHR has explained that the procedural guarantees concerning the operation of a habeas corpus procedure under Article 5(4) ECHR do not always necessarily have to be attended by the same guarantees as those required under Article 6, but they must have a judicial character and be effective. In particular, where an individual is detained in the context of criminal proceedings, a hearing is required. This means that the detainee must normally be heard in person. ${ }^{88}$

However, neither in the context of Article 6, nor under Article 5, the right to an oral hearing and personal physical presence operates as an absolute requirement. Thus, accordingly, the recourse to online hearings is not as such contrary to the requirements of the ECHR.

From the perspective of Article $6 \mathrm{ECHR}$, in some exceptional instances (cases concerning minor/administrative offences of technical/purely objective nature), the case may be examined without holding an oral hearing. ${ }^{89}$ At the same time, in some instances, the case may be heard remotely by using the relevant communication technologies.

In this latter connection, the ECtHR has accepted that an accused's participation in proceedings by videoconference is not as such contrary to the ECHR, neither in the appeal ${ }^{90}$ nor in the first-instance proceedings. ${ }^{91}$ However, recourse to this measure in any given case must serve a legitimate aim, such as prevention of disorder, prevention of crime, protection of witnesses and victims, compliance with the reasonable time requirement. In addition, the arrangements for the giving of evidence must be compatible with the requirements of due process. This means, in particular, that the accused must be able to: (a) see the persons present and hear what was being said, and (b) be seen and heard by the other participants, without technical impediments. Moreover, the accused must have an effective and confidential communication with a lawyer. ${ }^{92}$

It should also be noted that the ECtHR has accepted that in some instances participation of an accused in a hearing via video link may be a measure ensuring

Öcalan v Turkey [GC] (2005), par. 103.

Idalov v Russia [GC] (2012), par. 161.

Jussila, op. cit., note 84., par. 41-43; Sancakl v Turkey (2018), par. 45.

Grigoryevskikh v Russia (2009), par. 77 and 83.

Asciutto v Italy (2007), par. 62-63.

Marcello Viola v Italy (2006), par. 67 et seq.; Sakhnovskiy v Russia [GC] (201), par. 98. 
effective participation in the proceedings. ${ }^{93}$ In any event, the physical presence of an accused serves the greater goal of securing the fairness of the proceedings and is not an end in itself. ${ }^{94}$ It must therefore be seen in the context of the overall compliance with the procedural guarantees of a fair trial. ${ }^{95}$

With respect to the requirement of effective legal defence by a lawyer in this context, the ECtHR has stress that it must be respected "in all circumstances". ${ }^{96}$ Moreover, the ECtHR has held that the right to legal assistance takes on particular significance where the accused communicates with the courtroom via video link. ${ }^{97}$ Thus, the appointment of a lawyer to an accused who participates in the proceedings via video link may be required in the interest of justice. ${ }^{98}$

The effective legal representation implies, above all, the possibility of confidential communication between the accused and the lawyer. ${ }^{99}$ Thus, the provision of necessary communication technologies must be ensured in order to satisfy this requirement. The communication should be ensured prior to, and where needed, during the hearing ${ }^{100}$ and sufficient time should be provided for any consultations needed. ${ }^{101}$ There should be a possibility for the accused to have the presence of the lawyer next to her and/or in the hearing room. ${ }^{102}$ In any event, with respect to the limitations on the defence rights flowing from the recourse to online hearings, measures should be taken to compensate for any such limitations caused. ${ }^{103}$

Similar to the above considerations under Article 6, in the context of the decisions on pre-trial detention under Article 5 ECHR, the ECtHR has accepted that during a habeas corpus hearing the detainee's arguments may also be heard "through some form of representation”. ${ }^{104}$ In any event, Article 5(4) ECHR does not require that a hearing is held each time a decision on pre-trial detention is taken, but rather that such hearing is held in reasonable intervals. ${ }^{105}$

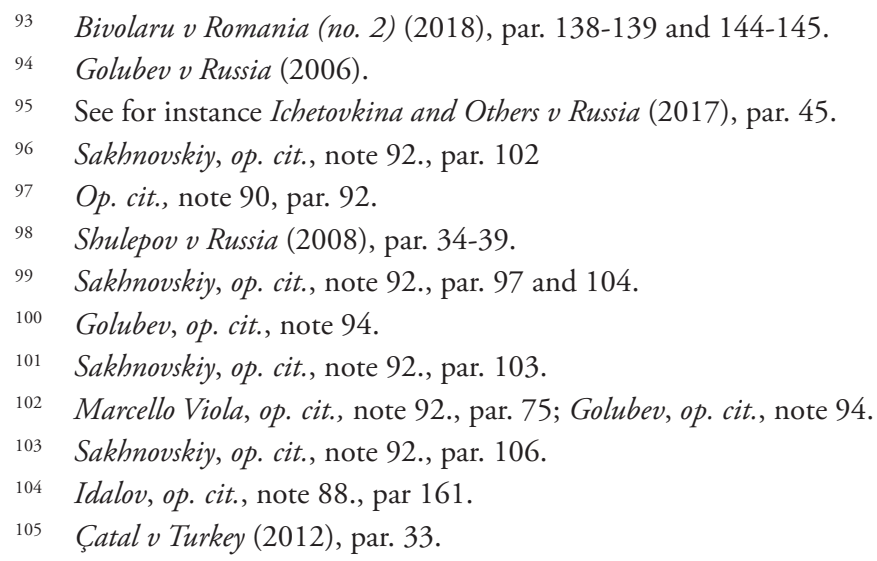


With respect to the first appearance of the arrested person, where, as noted above, the ECtHR has explicitly referred to a prompt physical appearance before a judicial officer, it has nevertheless accepted that such physical appearance may be delayed in very exceptional circumstances. ${ }^{106}$

It follows from these considerations that, although still not explicitly addressed in the case-law, it would be difficult to consider that in exceptional circumstances (such as the Covid pandemic), the prompt physical appearance before a judicial officer could not be ensured via communication technologies, provided, of course, that as soon as the circumstances cease to exist, the detainee is physically seen and heard by the relevant officer. Comparable requirements would then exist with respect to any subsequent bringing of the detainee before the court.

In this connection, in order to support the above conclusion, it may be useful to provide a more detailed analysis of one of the rare so far decided cases on the effects of the Covid pandemic.

In Fenech $v$ Malta ${ }^{107}$ the applicant (who is detained) complained under Article $5 \$ \$ 1$ (c) and 3 ECHR that the emergency measures introduced by the Maltese Government led to a postponement of the criminal proceedings against him and thus to a lack of foreseeability concerning his continued detention. He also complained under Article 6 ECHR about the restriction on his right of access to court and about the length of the criminal proceedings against him in relation to the suspension of the proceedings as a result of the Covid pandemic. The ECtHR disagreed with him on all the complaints, declaring them inadmissible as manifestly ill-founded.

With respect to Article $5 \mathrm{ECHR}$, the ECtHR noted that in reality the proceedings had been suspended for some three months as a result of the fact that the court work was stalled due to the Covid pandemic. However, this did not mean that the applicant's detention lost the purpose of bringing him before the component legal authority for trial, as required under Article $5 \$ 1$ (c). Moreover, the ECtHR remarked that the relevant domestic court had examined the applicant's requests for release on bail despite the closure of the court business at the time. For the ECtHR, from the perspective of Article $5 \$ 3$, it was also important to establish whether the domestic courts acted with due diligence. In this connection, the ECtHR stressed the following (par. 96):

\footnotetext{
106 Medvedyev and Others v France [GC] (2010), par. 127-134.

107 Op. cit., note 83.
} 
"[T] he Court notes that the applicant has not referred to any failings, delays or omissions on the part of the authorities, apart from the time during which the proceedings were suspended due to the emergency measures ... There is no indication that they were not being actively pursued before the emergency measures were put in place ... or afterwards. Moreover, this temporary suspension was due to the exceptional circumstances surrounding a global pandemic which ... justified such lawful measures in the interest of public health, as well as that of the applicant. It follows that it cannot be said that in the circumstances of the present case the duty of special diligence was not observed."

Similar reasoning led the ECtHR to declare the applicant's complaint under Article 6 inadmissible as manifestly ill-founded.

It thus follows that, in principle, the health risks associated with the Covid pandemic could justify the suspension of the court hearings for a certain period of time. However, the domestic authorities must show that they acted diligently and took measures to actively pursue the case and to respond to any relevant requests (such as release on bail) made by an accused during the suspension of the proceedings.

In sum, drawing from the existing Article 6 case-law, ${ }^{108}$ it follows that in the intermediary period (between the suspension of the proceedings and the possibility of ensuring a hearing in physical presence), the recourse to online hearings may be seen as a measure ensuring effective participation in the proceedings, provided, of course, that the relevant safeguards and the due process guarantees are put in place and effectively applied in practice.

\subsection{The Constitutional Court's case-law}

Since the beginning of the pandemic, ${ }^{109}$ the Constitutional Court has dealt with several cases regarding remote/online hearings. ${ }^{110}$ For the moment, these are only detention cases (urgent criminal cases), which the Constitutional Court can examine while the proceedings are still pending. ${ }^{111}$ The Constitutional Court has

\footnotetext{
108 See note 92.
}

109 In the context of the Covid pandemic, the Constitutional Court decided in several cases through abstract control of legislation, see cases Nos. U-I-1372/2020 et al. of 14 September 2020, U-II2379/2020 of 14 September 2020, U-II-2027/2020 of 14 September 2020, U-II-364/2021 of 23 February 2021, U-II-6087/2020 et al. of 23 February 2021, U-II-5920/2020 et al. of 3 February 2021, U-II-4784/2020 of 3 February 2021, U-I-5918/2020 et al. of 3 February 2021, U-II-1312/2020 of 14 September 2020, U-II-1430/2020 of 14 September 2020, etc.; accessed 1 April 2021.

110 Selected case-law derives from the period of 11 March 2020 to 15 April 2021; all decisions are available on the website of the Constitutional Court of the Republic of Croatia [www.usud.hr], last accessed 2 May 2021.

111 See also Article 63 of the Constitutional Act on the Constitutional Court of the Republic of Croatia, Official Gazette, No. 49/02 - Constitutional Court shall initiate proceedings even before all legal 
not yet examined, and has not yet received, any criminal or civil case decided on the merits where an issue of remote/online hearings during the Covid pandemic has been raised.

Article 29 of the Croatian Constitution ("Constitution") ${ }^{112}$ corresponds to Article 6 ECHR, and that is the provision which applicants most commonly invoked in their constitutional complaints. In addition, it should be pointed out that Article 22 of the Constitution corresponds to Article 5 (right to liberty) ECHR, which is the relevant provision invoked and applied in the pre-trial detention cases. Additionally, in some cases, applicants raised complaints about their health and health condition in detention, invoking Article 21 (1) of the Constitution, corresponding to Article 2 ECHR (right to life), as well as Article 23 (1) of the Constitution, corresponding to Article 3 ECHR (prohibition of torture).

In the first case No. U-III-3957/2020113, a hearing to decide whether to extend the pre-trial detention was held in the period of national lockdown ${ }^{114}$ in the absence of both the defendants and their lawyers, who proposed in a written statement (via e-mail) that the pre-trial detention measure be repealed. ${ }^{115}$ The applicant's lawyer

remedies have been exhausted in cases when the court of justice did not decide within a reasonable time about the rights and obligations of the party, or about the suspicion or accusation for a criminal offence, or in cases when the disputed individual act grossly violates constitutional rights.

Constitution of the Republic of Croatia, Official Gazette, Nos. 56/90, 135/97, 113/00, 28/01, 76/10 and $5 / 14$.

113 Decision No. U-III-3957/2020 of 22 September 2020.

114 In several cases, the applicants invoked the pandemic as a reason for the release from pre-trial detention or its replacement with the preventive measures, that is, in other words, as a reason why he/she could not commit the same or a similar criminal offence; see decisions No. U-III-1255/2020 of 22 April 2020, para 6.3.; U-III-1292/2020 of 29 April 2020, para 3.; U-III-1393/2020 of 19 May 2020, para 3.; U-III-2268/2020 of 4 June 2020, para 3.8.; U-III-3957/2020 of 22 September 2020, para 5.3. In case No. U-III-1255/2020, for instance, the applicant complained that at the time of the lockdown, the epidemiological situation in the Croatia decreased the possibility of reoffending since measures to combat the epidemic significantly prevented the commission of such criminal offences (unauthorised possession and trade in illicit drugs) without exposing the health of potential participants in the criminal offences. Moreover, it considers that, regardless of the above, the risk of reoffending could be eliminated by one of the preventive measures. The Constitutional Court did not accept these arguments as valid.

115 As to the applicant's allegations before the competent courts of the possibility of contagion in the prison in the circumstances of the Covid pandemic, the competent courts stated that no contagion had been detected within the prison. They also stated that according to the available data, the prison had previously been successful in preventing the spread of infectious diseases, so the court had no reason to believe it would not be the case in the future, and that during the current pandemic measures had been taken within the prison system to prevent the spread of the infection. Also, the competent court noted that the current pandemic is a circumstance that prevents the normal functioning of the court and its availability to the participants in the proceedings, but according to publicly available data of temporary and transitory nature and does not in itself constitute a reason for the quashing of pre-trial detention. 
sent a written statement to the court from his e-mail address, which is listed on the official website of the CBA. The disputed first-instance decision was served via prison, on 9 April 2020, on the applicant's lawyer's email address which had for years not been in use.

In the constitutional complaint, the applicant stated that his right to appeal under Article 18 para 1 of the Constitution had been violated due to the improper delivery on the wrong e-mail address of his lawyer. He further stated that he had been deprived of his liberty for four months without a valid and lawful court decision, which violated his right to liberty under Article 22 of the Constitution.

The Constitutional Court found that the first-instance and the appeal courts did not provide any reasons on why the disputed decision had been sent to the applicant's lawyer's earlier e-mail address and not to the one listed on the CBA website. The Court further found that due to the irregular delivery of the disputed decision via e-mail, the applicant's lawyer had been able to challenge the disputed first-instance decision only two months after its adoption. The Constitutional Court found that the first-instance court had not met the requirements of adversarial proceedings and equality of arms because it had not duly delivered the first-instance decision to the applicant's lawyers and thus violated the applicant right guaranteed by Article 24 para 3 of the Constitution, i.e. Article 5 (4) of the ECHR.

Further, cases Nos. U-III-3678/2020116 and U-III-1393/2020 $0^{117}$ concerned the adjournment of the hearings scheduled in the period of the national lockdown.

In case No. U-III-3678/2020, the first-instance court postponed the hearing scheduled for 6 April 2020 due to the pandemic and the national lockdown. In his constitutional complaint, the applicant pointed out that he had submitted extensive medical documentation to the lower courts confirming that his health condition was poor and that he needed to undergo a surgery, but the courts had failed to take that into account. He also contended that his physical disability made him unable to commit any criminal offence or reoffend.

The Constitutional Court pointed out that this case was an urgent case where delays were inacceptable as the case concerned the most severe restriction of the

116 Decision No. U-III-3678/2020 of 22 September 2020; all decisions and rulings are available on the website of the Constitutional Court of the Republic of Croatia [www.usud.hr], Accessed 16 April 2021.

117 Decision No. U-III-1393/2020 of 19 May 2020; in this case, constitutional complaint of the applicant is almost identical to the constitutional complaint in case No. U-III-3678/2020, consequently, the decision is almost the same. 
fundamental human right of individual liberty. However, the Court stressed that the competent authorities in criminal proceedings had to take the specific and objective circumstances into account (such as those relating to the pandemic) when taking the procedural actions. If they established the existence of extraordinary circumstances such as the pandemic due to which it was not possible to conduct a scheduled procedural action, even with the application of the protection measures, then they should provide sufficient reasons in that respect. In the absence of such reasons and having regard to the letter and the decision of the President of the Supreme Court, ${ }^{118}$ the Constitutional Court found no justification for the delays in the work of courts in the applicant's case, ${ }^{119}$ The Court therefore found a violation of Articles 22 and 25 para 2 of the Constitution.

At the same time, it dismissed the constitutional complaint in the part relating to the extension of the pre-trial detention and rejected the constitutional complaint in the part relating to a complaint about the provision of adequate health care to the applicant during his pre-trial detention. ${ }^{120}$

In case No. U-III-2269/2020 et al. ${ }^{121}$ the hearing during the national lockdown was held via video link with the applicant who was in prison. ${ }^{122}$ Referring to the pandemic, the applicant's lawyer requested that the pre-trial detention be replaced by one of the preventive measures because the applicant's stay in the pre-trial detention would pose risk to his health in the circumstances of the pandemic. The first-instance court found such a proposal by the applicant and his lawyer unfounded. Moreover, regarding the measures related to the pandemic, the firstinstance court stated that all measures were taken in the prison to prevent possible infections, and the same measures were taken by the court. Thus, a hearing to

118 See notes 47. and 48.

119 With regard to the applicant's complaint that he cannot receive adequate medical care in prison, the Constitutional Court reiterated that persons in pre-trial detention should complain about the conditions in pre-trial detention, including those related to health care, in accordance with Article 17 of the Enforcement of Prison Sentences Act, to the sentence-execution judge. An appeal against the decision of the sentence-execution judge is allowed to the three-member panel of the competent county courts. Only against such a decision, a constitutional complaint is allowed. Given that the applicant had not proved that he had exhausted the legal remedy under the Enforcement of Prison Sentences Act (Official Gazette Nos. 128/99, 55/00, 59/00, 129/00, 59/01, 67/01, 11/02, 76/07, 27/08, 83/09, 18/11, $48 / 11,125 / 11,56 / 13,150 / 13$ and 98/19) nor did he claim otherwise, the Constitutional Court could not examine the merits of the complaint concerning the lack of adequate health care and the incompatibility of the remand measure with the applicant's state of health.

120 As regards the applicant's complaint that he could not receive adequate medical care in prison, the Constitutional Court reiterated that persons in pre-trial detention should exhaust the remedies before the sentence-execution judge; see note 119.

121 Decisions no. U-III-2269/2020, et al. of 24 June 2020

122 See also decision no. U-III-2266/2020 of 16 June 2020 as a good example of a remote hearing. 
extend the pre-trial detention could be held via video link in order to avoid any contact with a defendant infected with the virus.

In the constitutional complaint, the applicant complained that there had been no special circumstances for extending the pre-trial detention. He also stated that his stay in detention in the circumstances of the pandemic would pose risk to his health, considering that it was impossible to ensure in detention even the least requisite protection from the virus.

The Constitutional Court accepted the findings of the relevant courts, especially regarding the explanation of the epidemiological situation in Croatia caused by the pandemic. It also held that all measures have been taken in the prison to successfully prevent the infections. Lastly, the Constitutional Court considered that the extension of the applicant's detention had been justified.

Another relevant case is case No. U-III-2173/2020, ${ }^{123}$ which concerned the decision on involuntary placement in a psychiatric institution of an applicant, who was not present at the hearing before the first-instance court, although the prosecutor and his ex offcio lawyer (whose appointment the applicant opposed) were present.

In particular, in this case the applicant had only once been heard by the judge via video link from the prison hospital. However, later the judge decided to hold a hearing scheduled at the time of the national lockdown at which the applicant needed to be examined. In this regard, the judge sent a letter to the prison hospital for the applicant to waive his right to participate in the hearing, and the applicant agreed to that signing the letter. The hearing was held in the absence of the applicant, but in the presence of the prosecutor and the applicant's ex offcio lawyer. At that hearing, the judge adopted a judgment ordering the applicant's psychiatric internment. All those present waived their right to appeal and the judgment, and an accompanying detention order, became final.

The applicant complained to the Constitutional Court contending, in particular, that he had been represented by an ex officio lawyer who had never communicated with him and had represented him against his will. Moreover, he argued that he had not been present at any hearing during the proceedings, including the last hearing, so that he had not been given the opportunity to present his defence and his evidence. He also stated that all his objections to the lower courts had been ignored.

123 See decision No. U-III-2173/2020 of 24 June 2020. 
The Constitutional Court agreed with the applicant and found multiple violations of the Constitution and the ECHR. In particular, in so far as relevant for the present discussion, the Constitutional Court found a violation of the right to an effective defence and the right to be tried in presence (Article 29 paras 2, 3, 4 and 5 of the Constitutions and Article 6 (3) (c) ECHR). It found that the trial judge had not heard the applicant and had failed to justify the applicant's nonparticipation at the hearing. In this connection, a mere reference to the pandemic did not suffice. The Constitutional Court did not consider that the applicant had made a valid waiver of his right to participate in the hearing. In addition, the Constitutional Court stressed that the judge conducting the proceedings had not provided any reasons for not hearing the applicant via video link at the relevant hearing. In this connection, the Constitutional Court stressed that the judge had been obliged under the relevant provisions of the Code of Criminal Procedure to inform the applicant about his rights and the consequences of his failure to act. The applicant should have also been instructed that he had the right to use legal remedies, which could be waived only after the judgment had been served on him. The Court also found that the ex officio lawyer had not protected the interests and rights of the applicant, and although she had been obliged to ensure the applicant's proper representation, she had failed to do that and remained passive during the proceedings.

It should also be noted that in several cases before the Constitutional Court, the applicants who challenged the decisions on their pre-trial detention referred exclusively to the health condition associated with the Covid pandemic. However, in many of those cases the relevant remedies had not been (properly) exhausted.

In case No. U-III-5334/2020, ${ }^{124}$ the applicant complained in relation to his health condition stating that he was in such a bad and life-threatening health condition that, regardless of his previous convictions, it was not advisable to keep him in detention. The Constitutional Court accepted the Supreme Court's explanation that the applicant had been provided with adequate medical care in detention, which was confirmed by the information available in the case.

In the next case No. U-III-2186/2020 the applicant complained about the prison overcrowding, as well as the health conditions and his state of health. He argued, in particular, that his stay in detention had significantly endangered his health and that the relevant sanitary measures against the pandemic had not been put in place. However, the Constitutional Court declared the applicant's complaints

124 Decision No. U-III-2186/2020 of 28 May 2020. 
inadmissible for his failure to exhaust the relevant remedy before the prison administration and the relevant courts.

In case No. U-III-3217/2020 ${ }^{125}$ the applicant complained that her life and health had been endangered by her detention because certain persons in the prison were positive for Covid virus (see also Decision No. U-III-2465/2020 of 29 July 2020). The Constitutional Court assessed this complain under Article 21 of the Constitution and Article 2 ECHR. In particular, the Constitutional Court stressed that the State should ensure that the health and well-being of detainees were adequately protected and that the detainees were provided with the necessary medical assistance. However, in the particular case at issue, the applicant had not raised her complaints before the relevant courts and thus her complaint was inadmissible for non-exhaustion of remedies (see, similarly, case No. U-III-414/2021 ${ }^{126}$ ).

\section{CONCLUSION}

There is no doubt that the various Covid measures severly impacted the functioning of justice systems, causing restrictions on the work of courts.

This article pointed to different aspects of the courts' functioning, which has been limited to varying degrees. There was a lack of consistent approach across courts, regarding the physical and procedural adaptations in response to the Covid pandemic, which is not surprising, since not all courts in all countries experienced the same issues. However, this seemed to indicate from the point of view of the parties and their procedural rights that the level of protection of the right to a fair trial and the health and safety of those involved in urgent criminal proceedings, as well as their right to liberty, varied depending on which court and which judge was competent for the proceedings. This, however, contributed to a sense of legal inequality and uncertainty. In this conection, as the article shows, resorting to remote justice and additional changes in policy during the Covid pandemic seriously limited access to justice and defence rights, including ability to exercise the right to legal assistance, to obtain access to the materials in the case file, etc. This is even more evident in a national context of pre-trial detention.

Some European countries (for instance Slovenia), in order to maintain legal certainty and security in the new circumstances and to ensure an equal level of humans' rights in court proceedings, provided legal framework to enable the functioning of courts and communication between courts and citizens. The CBA made a similar attempt in Croatia, proposing a draft Act on the Intervention Measures

\footnotetext{
125 Decision No. U-III-3217/2020 of 23 July 2020.

126 Decision No. U-III-414/2021 of 2 February 2021.
} 
in the area of judicial and administrative proceedings due to the Covid pandemic, which would have addressed, among other things, the regulation of audio-video link hearings. While this could have been welcomed by the parties and their representatives, the proposed Act was not adopted.

Compared to the effect of the Covid pandemic on other European countries, Croatia is no exception. The Constitutional Court's case-law is an example that when it comes to the cases in which a hearing was scheduled at the time of a national lockdown, the competent courts acted differently, regardless of the recommendations of the Ministry of Justice and the decisions and recommendation of the President of the Supreme Court. The Constitutional Court has so far found a violation of several Articles of the Constitution (and ECHR) in several decisions in relation to online hearings (the right to adversarial proceedings, equality of arms, effective legal representation, etc. as the aspects of the right to a fair trial, also right to liberty, etc.).

Drawing from the existing ECtHR case-law, neither in the context of Article 6, nor under Article 5 of the ECHR, the right to an oral hearing and personal physical presence operates as an absolute requirement. The recourse to remote/online hearings is possible but it must pursue a legitimate aim and must be accompanied with the relevant procedural safeguards. Moreover, in the context of the Covid pandemic, the domestic authorities must show that they acted diligently and took measures to actively pursue the case and to respond to any relevant requests made by an accused.

Nonetheless, the experience of the Covid pandemic and other emergency situations, has shown that when determining measures, the courts should consider how to maintain a balance between the requirements of clarity and foreseeability of their decisions and their case management solutions, on the one hand, and the flexibility of their decision-making, on the other. While many questions still remain open, the main considerations from the analysis of the ECtHR's and the Constitutional Court's case-law (notably on remote/online hearings) could certainly assist the courts during the pandemic and inform their decisions on the manner in which the Covid pandemic experience with the administration of justice can be taken forward. 


\section{REFERENCES}

\section{BOOKS AND ARTICLES}

1. Aebi, M.F.; Tiago, M.M., Prisons and Prisoners in Europe in Pandemic Times: An evaluation of the medium-term impact of the COVID-19 on prison populations, Council of Europe Annual Penal Statistics, Strasbourg, Lausanne, December 2020

2. Babcock, E.; Johansen, K., Remote Justice? Expanding the Use of Interactive Video Teleconference in Minnesota Criminal Proceedings, William Mitchel Law Review, Vol. 37, No. 2, 2011, pp. 652-682

3. Kamber, K., Measures related to health issues, Regional online round table The impact of the COVID-19 pandemic on human rights and the rule of law, Strasbourg, 28 April 2020

4. Legg, M., The COVID-19 Pandemic, the Courts and Online Hearings: Maintaining Open Justice, Procedural Fairness and Impartiality, Federal Law Review, Vol. 49, 2021, pp. 20-46

5. Lenaerts, K., Federalism and the Rule of Law: Perspectives from the European Court of Justice, Fordham International Law Journal, Vol. 33, No. 5, 2011

6. McKeever, G., Remote Justice? Litigants in Person and Participation in Court Processes during Covid-19, Modern Law Review, No. 5, 2020

7. Peršak, N., Editorial: COVID-19 and the Social Responses thereto: Penal and Criminological Lessons, Human Rights and Rule of Law Implications, European journal of crime, criminal law and criminal justice, Vol. 28, 2020, pp. 205-216

8. Popotas, C., COVID-19 and the Courts The case of the CJEU' Access to Justice in Eastern Europe, Vol. 2-3, No. 7, 2020, pp. 160-171

9. Ritscher, C., COVID-19 and International Crimes Trials in Germany, Journal of International Criminal Justice, 2021, pp. 1-4

10. Spano, R., The rule of law as the lodestar of the European Convention on Human Rights: The Strasbourg Court and the independence of the judiciary, European Law Journal, 2021

11. Susskind, R., Online Courts and the Future of Justice, Oxford University Press, Oxford, 2019

12. Turner, J.I., Remote Criminal Justice, Texas Tech Law Review, Vol. 53, No. 2, 2021, pp. 198271

\section{EU LAW}

1. Green Paper Strengthening mutual trust in the European judicial area - A Green Paper on the application of EU criminal justice legislation in the field of detention

2. Protocol (no 3) on the Statute of the Court of Justice of the European Union, Official Journal of the European Union, C 202/210

\section{ECtHR}

1. ECtHR's Guide on Article 6 of the European Convention on Human Rights: Right to a fair trial (criminal limb), Strasbourg, 2021

2. ECtHR's Guide on Article 5 of the European Convention on Human Rights: Right to liberty and security, Strasbourg, 2020. 
3. European Commission for Democracy through Law (Venice Commission), Report - Respect for Democracy Human Rights and Rule of Law during States of Emergency - Reflections, CDL-PI(2020)005rev, 26 May 2020;

4. Council of Europe Secretary General, Respecting democracy, rule of law and human rights in the framework of the COVID-19 sanitary crisis: A toolkit for member states, SG/ Inf(2020)11, 7 April 2020

5. The European Commission for the Efficiency of Justice (CEPEJ) Declaration Lessons learnt and challenges faced by the judiciary during and after the COVID-19 pandemic, CEPEJ, Ad hoc virtual CEPEJ plenary meeting, Strasbourg, 10 June 2020

6. Consultative Council of European Judges (CCJE), Statement of the President of The CCJE, The role of judges during and in the aftermath of the COVID-19 pandemic: lessons and challenges, CCJE(2020)2, 24 June 2020.

7. CEPEJ, Management of the judiciary - compilation of comments and comments by country, 10 July 2020

8. Consultative Council of European Prosecutors (CCPE) Opinion No. 15 (2020): The role of prosecutors in emergency situations, in particular when facing a pandemic, Strasbourg, November 2020.

9. Council of Bars and Law Societies of Europe (CCBE) Survey: exchange of experiences and best practices between bars", 2020

10. CCBE, Questionnaire Restrictions on court working, Croatia, pp-13-15

11. The Functioning of Courts in the COVID-19 Pandemic: Primer, October 2020,

12. The ECHR and the Pandemic - Rule of Law as the Lodestar of the Convention System, speech by Robert Ragnar Spano, President of the ECtHR, held on the Seventh Regional Rule of Law Forum for South-East Europe, 16 and 17 October 2020

13. Coronavirus Pandemic in The EU - Fundamental Rights Implications: With A Focus on Contact-Tracing Apps, Fundamental Rights Agency, Bulletin No. 2, 21 March - 30 April 2020, European Union Agency for Fundamental Rights, 2020

14. Coronavirus pandemic in the EU - Fundamental Rights Implications, Croatia, Centre for Peace Studies, Human Rights House, 2 July 2020

\section{LIST OF NATIONAL REGULATIONS, ACTS AND COURT DECISIONS}

\section{DECISIONS RETRIEVED FROM HUDOC}

1. Golubev v Russia, No. 26260/02, 9.11.2006

2. Feilazoo v Malta, No. 6865/19, 11.03.2021

3. Fenech v Malta, No. 19090/20, 23.03.2021

4. Le Mailloux v France, No. 18108/20, 05.11.2020

\section{JUDGMENTS RETRIEVED FROM HUDOC}

1. Asciutto v Italy, No. 35795/02, 27.11.2007

2. Bivolaru v Romania (no. 2), No. 66580/12 02.10.2018 
3. Çatal v Turkey, No. 26808/08, 17.04.2012

4. Grigoryevskikh v Russia, No. 22/03, 09.04.2009

5. Hermi v Italy, No. 18114/02, 18.10.2006

6. Ichetovkina and Others v Russia (2017), Nos. 12584/05 and 5 others, 04.07.2017

7. Idalov v Russia, No. 5826/03, 22.05.2012

8. Jussila v Finland, No. 73053/01, 23.11.2006

9. Khoroshenko v Russia, No. 41418/04, 30.06.2015

10. Marcello Viola v Italy, No. 45106/04, 05.10.2006

11. Medvedev v Russia, No. 10932/06, 03.10.2017

12. Öcalan v Turkey, No. 46221/99, 12.05.2005

13. Sakhnovskiy v Russia, No. 21272/03, 02.11.2010

14. Sanader v Croatia, No. 664082/12, 12.02.2015

15. Sancaklıv Turkey, No. 1385/07, 15.05.2018

16. Shulepov v Russia, No. 15435/03, 26.06.2008

17. Zahirović v Croatia, No. 58590/11, 25.04.2013

\section{NATIONAL REGULATIONS}

1. Act on Interim Measures in Relation to Judicial, Administrative and Other public law matters for the control of the spread of the infectious disease SARS-CoV-2 (COVID-19), Official Gazette of the Republic of Slovenia 36/20

2. Act to Mitigate the Consequences of the COVID-19 Pandemic under Civil, Insolvency and Criminal Procedure Law of 27 March 2020, (Gesetz zur Abmilderung der Folgen der COVID-19-Pandemie im Zivil-, Insolvenz- und Strafverfahrensrecht, BGBl. I Nr. 14, 27. 3. 2020)

3. Civil Procedure Act, Official Gazette 53/91, 91/92, 112/99, 88/01, 117/03, 82/05, 02/07, 84/08, 96/08, 123/08, 57/11, 25/13, 89/14 28/13, 70/19

4. Constitution of the Republic of Croatia, Official Gazette 56/90, 135/97, 113/00, 28/01, $76 / 10,5 / 14$.

5. Constitutional Act on the Constitutional Court of the Republic of Croatia, Official Gazette 49/02

6. Criminal Procedure Act, Official Gazette 52/08, 76/09, 80/11, 121/11, 91/12, 143/12, 56/13, 145/13, 152/14, 70/17, 126/19

7. Enforcement of Prison Sentences Act, Official Gazette 128/99, 55/00, 59/00, 129/00, 59/01, 67/01, 11/02, 76/07, 27/08, 83/09, 18/11, 48/11, 125/11, 56/13, 150/13, 98/19

8. Recommendation of the Ministry of Justice of 13 March 2020

9. Recommendation of the Ministry of Justice of 17 March 2020

10. Resolution 44/9 (16 July 2020), Independence and impartiality of the judiciary, jurors and assessors, and the independence of lawyers 


\section{SUPREME COURT OF THE REPUBLIC OF CROATIA}

1. Recommendation no. Su-IV-125/20-2 of 13 March 2020

2. Letter no. Su-IV-125/2020-5 of 20 March 2020

3. Decision no. Su-V-125/2020-50 of 31 March 2020

\section{DECISION OF THE CONSTITUTIONAL COURT OF THE REPUBLIC OF CROATIA}

1. U-I-1372/2020 et al. of 14 September 2020

2. U-II-2379/2020 of 14 September 2020

3. U-II-2027/2020 of 14 September 2020

4. U-II-364/2021 of 23 February 2021

5. U-II-6087/2020 et al. of 23 February 2021

6. U-II-5920/2020 et al. of 3 February 2021

7. U-II-4784/2020 of 3 February 2021

8. U-I-5918/2020 et al. of 3 February 2021

9. U-II-1312/2020 of 14 September 2020

10. U-II-1430/2020 of 14 September 2020

11. U-III-3957/2020 of 22 September 2020

12. U-III-1255/2020 of 22 April 2020

13. U-III-1292/2020 of 29 April 2020

14. U-III-1393/2020 of 19 May 2020

15. U-III-2268/2020 of 4 June 2020

16. U-III-3957/2020 of 22 September 2020

17. U-III-3678/2020 of 22 September 2020

18. U-III-2269/2020, et al. of 24 June 2020

19. U-III-2266/2020 of 16 June 2020

20. U-III-2173/2020 of 24 June 2020

21. U-III-2186/2020 of 28 May 2020

22. U-III-3217/2020 of 23 July 2020

23. U-III-414/2021 of 2 February 2021

\section{WEBSITE REFERENCES}

1. [www.ccbe.eu], Accessed 15 April 2021

2. [www.coe.int], Accessed 15 April 2021

3. [https://curia.europa.eu/], Accessed 15 April 2021

4. [www.ec.europa.eu], Accessed 15 April 2021

5. [https://eur-lex.europa.eu], Accessed 15 April 2021

6. [www.fra.europa.eu], Accessed 15 April 2021 
7. [www.fairtrials.org], Accessed 15 April 2021

8. [www.hok-cba.hr], Accessed 15 April 2021

9. [www.hudoc.echr.coe.int], Accessed 15 April 2021

10. [www.icj.org], Accessed 15 April 2021

11. [www.koronavirus.hr], Accessed 15 April 2021

12. [www.mpu.gov.hr], Accessed 15 April 2021

13. [www.ohchr.org], Accessed 15 April 2021

14. [www.osce.org], Accessed 15 April 2021

15. [www.prisonobservatory.org], Accessed 15 April 2021

16. [www.prisonstudies.org], Accessed 15 April 2021

17. [http://sudovi.pravosudje.hr/], Accessed 15 April 2021

18. [www.usud.hr], Accessed 15 April 2021

19. [www.vsrh.hr], Accessed 15 April 2021

20. Earthquakes in Zagreb from March 22 to April 14, 2020, [https:/www.pmf.unizg.hr/geof/ seizmoloska_sluzba/o_zagrebackom_potresu_2020?@=1lrg6], Accessed 15 April 2021

21. e-communication, [https://usluge.pravosudje.hr/komunikacija-sa-sudom/, accessed 16 April 2021, https://pravosudje.gov.hr/vijesti/ekomunikacija-priblizava-sudove-gradjanima/21945], Accessed 16 April 2021 